\title{
PROFIL BERPIKIR REFLEKTIF SISWA DALAM MENYELESAIKAN SOAL LUAS LINGKARAN DITINJAU DARI PERBEDAAN KEMAMPUAN MATEMATIKA DAN GENDER
}

\author{
Yunia Maya Avianti ${ }^{1}$, Novisita Ratu ${ }^{2}$ \\ ${ }^{1,2}$ Universitas Kristen Satya Wacana, Jl. Diponegoro No.52-60 Salatiga, 50711 \\ 202016021@student.uksw.edu
}

\begin{abstract}
The ability in reflective thinking is a potential in developing a previously obtained mindset that can conclude an existing problem. This research is a qualitative descriptive because it is used to describe the profile of reflective thinking students in resolving area of a circle of problems are reviewed from differing levels of ability and gender. It consists of 3 female subjects and 3 male subjects of grade IX junior high school who have high mathematical abilities, medium abilities and low abilities. So the results of the study stated that women of high ability, men of high ability and subjects of women of medium ability have high reflective thinking abilities. The subjects of men with moderate mathematical abilities and women with low abilities have quite reflective abilities. And low-ability male subjects have less reflective abilities. In this research also found that female subjects prefer to finish in a coherent way by writing the known of the assigment, what is asked and answered questions while male subjects use the example of drawing and completing it directly
\end{abstract}

Keywords: reflektiive thinking, area of a circle, mathematical ability, gender

\begin{abstract}
Abstrak
Kemampuan dalam berpikir reflektif yaitu suatu potensi dalam mengembangkan pola pikir yang didapatkan sebelumnya sehingga dapat menyimpulkan suatu permasalahan yang ada. Penelitian ini bertujuan untuk mengetahui hubungan menarik terhadap berpikir reflektif dalam menyelesaikan masalah, perbedaan jenjang kemampuan berpikir matematika dan perbedaan gender. Pentingnya Penelitian ini untuk mengetahui adakah perbedaan yang signifikan antara perempuan dan laki-laki yang mempunyai perbedaan kemampuan berpikir. Penelitian ini adalah deskriptif kualitatif karena dipergunakan untuk mendiskripsikan profil berpikir reflektif siswa dalam menyelesaikan masalah luas lingkaran ditinjau dari perbedaan tingkat kemampuan dan gender. Terdiri dari 3 subjek perempuan dan 3 subjek laki-laki kelas IX SMP yang punya kemampuan matematika yang tinggi, kemampuan yang sedang dan kemampuan yang rendah. Maka hasil dari penelitian menyatakan bahwa perempuan kemampuan tinggi dan laki-laki kemampuan tinggi memiliki kemampuan reflektif tinggi, sedangkan subjek perempuan kemampuan sedang juga memiliki kemampuan berpikir reflektif tinggi. Subjek laki-laki kemampuan matematika sedang dan perempuan kemampuan rendah memiliki kemamapuan cukup reflektif. Dan subjek laki-laki kemampuan yang rendah memiliki kemampuan kurang reflektif. Dalam pernelitian ini juga ditemukan jika subjek perempuan lebih memilih menyelesaiakan dengan cara yang runtut dengan menuliskan diketahui, ditanya dan jawab sedangkan subjek laki-laki menggunakan permisalan gambar dan menyelesaikan secara langsung
\end{abstract}

Kata Kunci: Berpikir Reflektif, Luas Lingkaran, Kemampuan Matematika, Gender

\section{PENDAHULUAN}

Berpikir merupakan suatu kegiatan yang memicu otak untuk bekerja dan dituangkan dalam sebuah konsep atau ide. Diawali dengan cara memikirkan sesuatu manusia bisa melaksanakan pekerjaan jasmani atau batin secara normal. Tidak hanya memicu otak, berpikir melibatkan seluruh kehendak dan perasaan manusia (Suriasumantri, n.d.). Berpikir merupakan suatu cara untuk memusatkan pikiran pada suatu objek, yang dilakukan dengan sadar sehingga dapat tergambarkan dalam pikiran suatu topik tertentu. 
Kemampuan bepikir merupakan acuan dari keberhasilan suatu tujuan pembelajaran matematika terlebih berpikir tingkat tinggi, contohnya berpikir kreatif, kritis dan reflektif. Berpikir reflektif menjadi salah satu kemampuan dalam bepikir yang menggunakan subjek sebagai objek. Menurut Supriyaningsih (2016) berpikir merupakan salah satu faktor penentu dalam menyelesaiakan masalah matematika. Tahap berpikir reflektif yaitu mengecek ulang suatu cara baru yang telah dipakai, mengkaji dan mengaitkan formasi yang sudah dimiliki seluruh bagian berdasarkan ingatan untuk mengkoreksi bahkan mengadopsi pada cara dan menemukan suatu cara yang baru. Berpikir reflektif yaitu melibatkan suatu pertimbangan yang aktif terhadap pengetahuan yang mempergunakan ingatan dalam menyimpulkan permasalahan dengan berbagai pandangan. Kemampuan berpikir reflektif adalah kemampuan yang mengabungkan suatu informasi yang telah didapatkan dengan informasi yang baru sehingga menemukan kesimpulan dalam suatu masalah. (Ariestyan, Y. Sunardi, Kurniati, 2016) Untuk menilai kemampuan berpikir reflektif siswa, guru melakukan dengan cara memberikan kegiatan yang bisa menunjang siswa untuk mengasah kemampuannya.

Ada sejumlah peneliti yang melakukan penelitian tentang berfikir reflektif antara lain,penelitian yang dikerjakan oleh (Putri \& Mampouw, 2018) tentang berpikir reflektif siswa dalam penyelesaian soal tipe perkalian dari perbedaan gender dan kemampuan matematika. Penelitian oleh (Fuady, 2017) tentang berpikir reflektif dalam masalah matematika. Masalah matematika didalam kegiatan sehari-hari biasanya disajikan dari soal-soal yang mengandung tentang kemampuan penyelesain masalah.

Penyelesaian masalah merupakan aturan kompleks yang dapat dicapai melalui setelah menguasai aturan dan konsep yang terdefinisi (Purwokerto \& Belakang, 2018). Penyelesaian masalah memiliki berbagai arti, salah satunya penyelesaian masalah merupakan sebuah tujuan. Kecerdasan adalah proses menyeluruh sebagai jalannya cara berpikir dalam menyelesaikan suatu masalah. Kesimpulannya penyelesaian masalah yaitu metode berpikir tingkat tinggi untuk mengembangkan kecakapan berpikir. Ulvah (2016), berpendapat penyelesaian masalah merupakan tujuan dari pembelajaran matematika

Penyelesaian masalah matematika masing-masing orang mempunyai metode yang beda satu sama lain, hal itu bisa berlangsung dikarenakan setiap individu memiliki kemampuan berpikir yang beda satu sama lain. Tetapi hal tersebut sangat penting untuk menyelesaikan suatu masalah yang ada. Orang yang memiliki jenjang kemampuan tinggi bisa menyelesaikan masalah dengan benar. Orang dengan jenjang kemampuan sedang menyelesaikan dengan cukup benar, sedangkan jenjang kemampuan rendah cenderung kurang benar (Nurman, 2008).

(Demirel, M., Derman, I., \& Karagedik, 2015) mengungkapkan dalam proses penyelesaain masalah dengan berpikir reflektif terdapat perbedaan antar gender. (Tuncer, M. Ozeren, 2012) Mengatakan bahwa gender tidak berpengaruh dalam proses berpikir reflektif dalam menghadapi suatu masalah. Maka akan diteliti untuk membuktikan bahwa dalam menyelesaiakan permasalahan dapat melihat perbedaan gender. 
Berdasarkan uraian diatas diperoleh hubungan menarik terhadap berpikir reflektif dalam menyelesaikan masalah, perbedaan jenjang kemampuan berpikir matematika dan perbedaan jenis kelamin. Tujuan dari penelitian ini yaitu mendeskripsikan cara berpikir reflektif bagi siswa dalam mengerjakan soal luas lingkaran yang ditinjau dari perbedaan kemampuan matematika dan gender.

\section{METODE}

Dalam pengkajian ini menggunakan Deskriptif Kualitatif dengan harapan untuk dapat mendiskripsikan profil berpikir reflektif siswa dalam mengerjakan masalah luas lingkaran berdasarkan pada langkah berpikir reflektif Surbeck Hand Moyer. Deskriptif kualitiatif yaitu mendeskripsikan atau mengambarkan peristiwa-peristiwa yang menjadi fokus penelitian. Data yang didapatkan dalam bentuk kata-kata atau lisan yang didapatkan dari wawancara dan tulisan berbentuk angka-angka atau bilangan yang didapatkan dari hasil wawancara dan pemberian soal. Subjek penelitian ini dipilih dari SMP Negeri 6 Salatiga yang merupakan 3 subjek laki-laki dan 3 subjek perempuan kelas IX A. Tolak ukur kemampuan matematika berdasarkan pada penililaian UTS (Ulangan tengah semester 1) tahun ajaran 2019/2020. Pemilihan subjek yang telah menerima materi lingkaran (Sugiyono, 2015) mengatakan purposive sampling yaitu teknik pengambilan subjek yang dipertimbangankan atau dipilih dengan ketentuan tertentu, maka penelitian ini menggunakan cara pengambilan data dengan purposive sampling.

Berikut merupakan data subjek penelitian.

\section{Tabel 1.}

Data Subjek Penelitian

\begin{tabular}{|c|c|c|}
\hline Subjek & Gender & Kategori Kemampuan \\
\hline S1 & Perempuan & Tinggi \\
\hline S2 & Laki-laki & Tinggi \\
\hline S3 & Perempuann & Sedang \\
\hline S4 & Laki-laki & Sedang \\
\hline S5 & Perempuan & Rendah \\
\hline S6 & Laki-laki & Rendah \\
\hline
\end{tabular}

Tabel 2.

Indikator Berpikir Reflektif

\begin{tabular}{|c|l|}
\hline Fase Berpikir Reflektif & \multicolumn{1}{|c|}{ Indikator } \\
\hline \multicolumn{1}{|c|}{ Reacting } & $\begin{array}{l}\text { Mampu menuliskan dan mengucapkan informasi yang } \\
\text { diketahui dalam saol dan ditanyakan }\end{array}$ \\
\hline Elaborating/Comparing & $\begin{array}{l}\text { Menjabarkan respon dalam persoalan yang telah dikerjakan } \\
\text { lalu menghubungkan persoalkan pada masalah yang sudah } \\
\text { diselesaikan. }\end{array}$ \\
\hline Contemplanting & $\begin{array}{l}\text { Mengecek jawaban sesuai dengan kebenaran suatu pendapat } \\
\text { berdasarkan cara yang digunakan untuk dapat menyimpulkan } \\
\text { dengan benar }\end{array}$ \\
\hline
\end{tabular}

Sumber : Modifikasi dari (Ananda) 


\section{Fase berpikir reflektif diklasifikasikan, yaitu:}

\section{Reflektif}

Fase ini dapat disimpulkan reflektif melewati fase reacting, elaborating/comparing, dan contemplanting.

\section{Cukup reflektif}

Dapat disimpulkan cukup reflektif jika melewati fase reacting juga elaborating.

Kurang reflektif

Dapat disimpulkan kurang reflektif jika melewati fase reacting saja atau bahkan tidak melalui fase apapun.

Sumber : Modifikasi dari (kartika dian)

\section{HASIL}

\section{Subjek Perempuan kemampuan Matematika yang Tinggi}

Bersumber pada hasil analisa tes didukung oleh wawancara yang telah diselesaikan pada subjek S1.

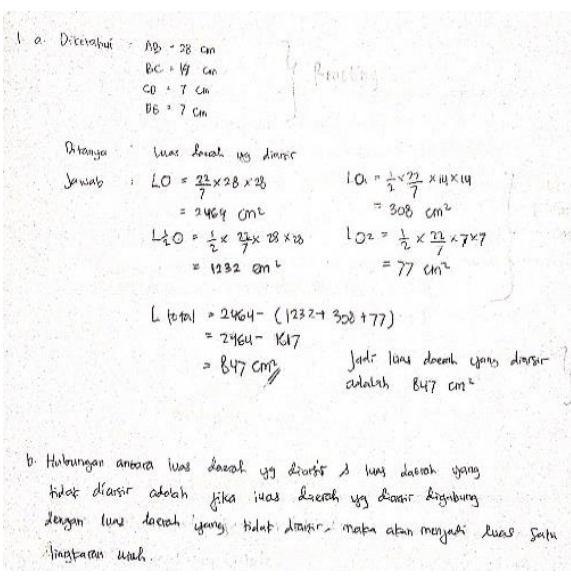

Gambar 1. Hasil Tes S1

Berdasarkan jawaban subjek S1 pada gambar 1, subjek S1 dalam fase reacting mampu mengerti persoalan yang diberikan sehingga mampu menuliskan dan menyebutkan semua informasi yang ditanya dalam soal. Berikutnya pada fase elaborating/comparing dapat menjawab dengan mejelaskan jawaban yang dihasilkan dari permasalhan yang telah dikerjakan dan mendapatkan persamaan dan perbedaan pada persoalan yang sudah ditemukan sebelumnya dengan masalah yang baru dikerjakan. Fase contemplating S1 mampu mengerjakan secara rinci, dan dapat menyimpulkan dengan benar pada soal yang dikerjakan. Jadi bisa disimpulkan S1 perempuan berkemapuan tinggi mempunyai kemampuan untuk berpikir reflektif pada soal luas lingkaran.

\section{Subjek Laki-laki Kemampuan Matematika yang Tinggi}

Bersumber pada analisa hasil tes dan didukung dengan oleh hasil wawancara dengan S2 diperoleh dalam gambar 2 dalam fase reacting, mampu mengerti pemasalahan yang disajikan, 
sanggup menuturkan informasi yang telah diketahui dan dipertanyakan pada masalah yang diberikan. Pada fase reacting ini juga, subjek S2 mampu mendapatkan hubungan dari yang sudah diketahui dan apa ditanyakan dalam soal. Berikutnya pada fase elaborating/comparing dapat menjawab dengan mejelaskan hasil yang diperoleh dari masalah yang sudah dihadapi dan mendapatkan suatu pernyataan pada masalah yang telah dihadapi sebelumnya dan masalah yang sedang dikerjakan. Subjek S2 memberikan alasan pada jawaban yang sudah dikerjakan dengan mengambarkan sketsa lingkaran sebagai jembatan dalam menyelesaikan permasalahan. Fase contemplating subjek S2 mampu menyelesaikan permasalahan pada soal dan memberikan kesimpulan dengan tepat melalui tahap evaluasi. Berdasarkan penjelasan singkat diatas bisa disimpulkan jika S2 laki laki berkemampuan matematika yang tinggi mempunyai kemampuan dalam berpikir reflektif pada luas lingkaran.

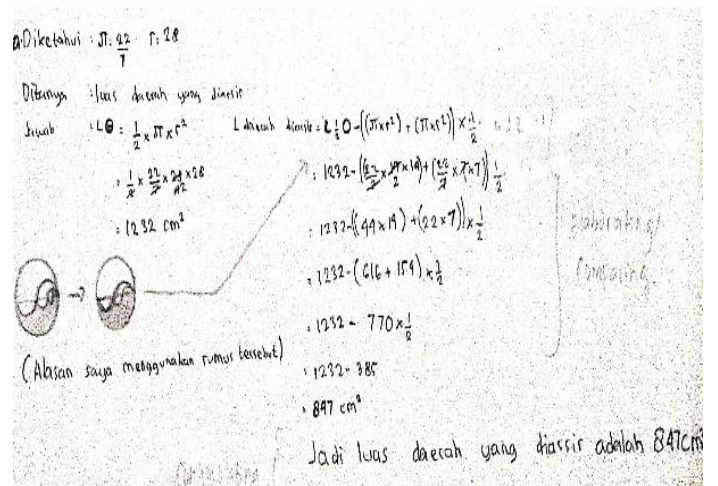

Gambar 2. Hasil Tes S2

\section{Subjek Perempuan Kemampuan Matematika yang Sedang}

Bersumber pada analisa hasil tes tertulis dan wawancara S3 yang terdapat pada gambar 3.

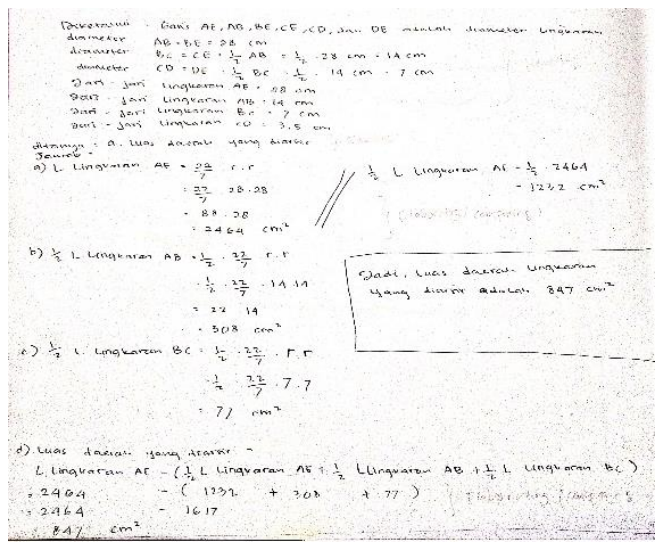

Gambar 3. Hasil Tes S3

Berdasarkan pada gambar 3 diatas ditemukan dalam fase reacting subjek mampu mengerti permasalahan yang diberikan, menuliskan dan mengatakan apa saya yang diketahui dengan lengkap dan rinci, serta bisa menangkap yang ditanyakan dalam soal. Pada fase elaborating/comparing S3 
bisa mengungkapkan dengan detail jawaban yang diperoleh. Dalam menyelesaikan persoalan yang ada, S3 memakai cara yang sudah pernah didapatkan sebelumnya dan mengaitkan dengan cara subjek sendiri sesuai pemahamnnya. Berikutnya pada fase contemplating subjek S3 mampu menyelesaikan permasalahan sampai pada akhir dan dapat membuat kesimpulan dengan tepat. subjek S3 juga mampu menguatkan argumennya bahwa ia dapat mengerjakan permasalahan dengan benar. Maka dari penjelasan diatas bisa disimpulkan S3 perempuan kemampuan matematika yang sedang mempunyai kemampuan dalam berpikir reflektif pada luas lingkaran.

\section{Subjek Laki-laki Kemampuan Matematika yang Sedang}

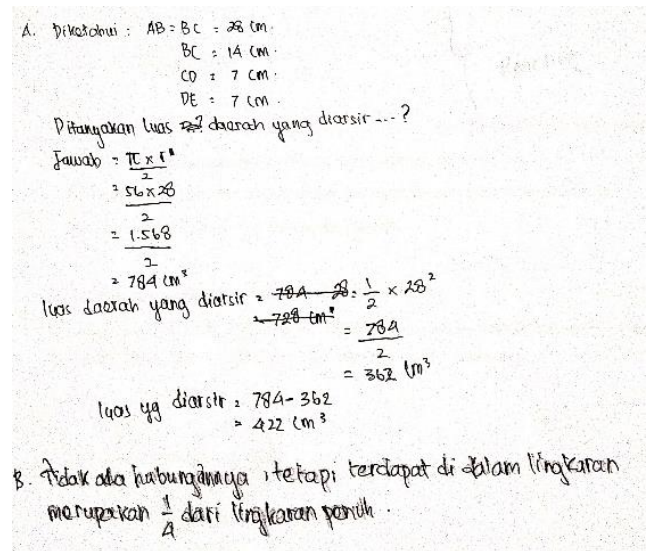

Gambar 4. Hasil Tes S4

Berdasarkan pada gambar 4 diatas memperoleh hasil dalam fase reacting mampu mengetahui persoalan yang diberikan. Menyebutkan informasi yang diketahui dan dipertanyakan dalam soal. Fase elaborating/comparing subjek S4 mampu menjelaskan jawabannya menurut pemahaman subjek S4. Selanjutnya pada fase contemplating subjek S4 mampu menyelesaiakn permasalahan sampai pada akhirnya dan dapat membuat kesimpulan, tetapi kesimpulan yang diberikan oleh subjek masih belum tepat.

Bisa disimpulkan, S4 laki-laki berkemampuan sedang mempunyai kemampuan cukup reflektif dikarenakan hanya melewati fase reacting dan elaborating/comparing pada luas lingkaran.

\section{Subjek Perempuan kemampuan Matematika yang Rendah}

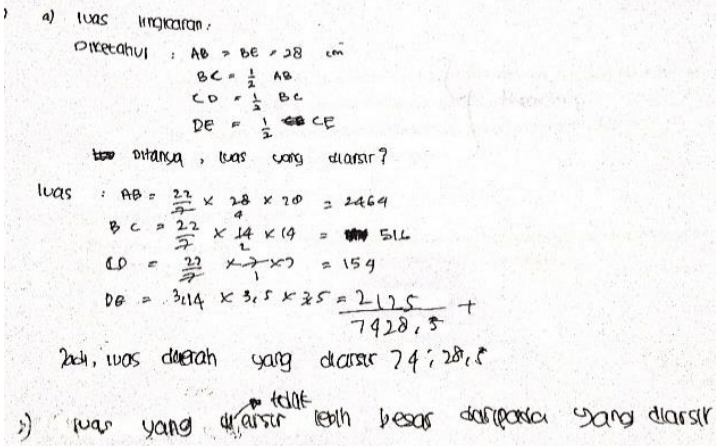

Gambar 5. Hasil Tes S5 
Berdasarkan hasil tertulis S5 diatas, subjek berhasil menuliskan data-data yang ada pada soal secara baik, dan bisa memahami pertanyaan dalam soal dengan benar sehingga memenuhi fase reacting. Fase elaborating / comparing S5 bisa mengungkapkan hasil yang sudah dikerjakan. Berikutnya fase contemplanting subjek S5 dapat memberikan kesimpulan atas jawaban yang sudah ia dapatkan tetapi kesimpulan yang diberikan belum tepat. Jadi bisa ditarik simpulan S5 perempuan kemampuan rendah mempunyai kemampuan cukup reflektif pada luas lingkaran.

\section{Subjek Laki-laki Kemampuan Matematika yang Rendah}

Subjek S6 berdasarkan tes tertulis dan wawancara pada fase reacting subjek tidak bisa menuturkan informasi yang diketahui dalam soal dan juga yang dipertanyakan. Berikutnya dalam fase elaborating/comparing subjek bisa Menjelaskan jawabannya menurut pemahamannya sendiri. Pada fase contemplanting subjek S6 tidak dapat memberikan kesimpulan atas jawabannya, subjek kurang yakin dengan pekerjaan yang sudah diselesaikan. Maka dapat ditarik kesimpulan dari penjelasan diatas bahwa subjek S6 hanya memenuhi fase elaborating/comparing sehingga subjek S6 laki-laki kemampuan yang rendah memiliki kemampuan kurang reflektif. Dapat dilihat pada gambar 6 dibawah ini.

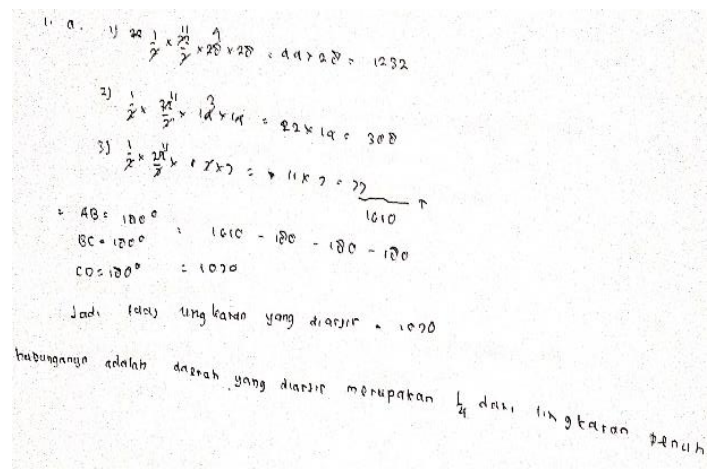

Gambar 6. Hasil Tes S6

Berdasarkan hasil pembahasan yang sudah dijelaskan diatas diperoleh kemampuan berpikir reflektif pada luas lingkaran. Adapun ringkasan kemampuan reflektif bisa dilihat pada tabel 3 .

\section{Tabel 3.}

Ringkasan Kemampuan Reflektif

\begin{tabular}{|c|c|c|}
\hline Subjek & Kategori Kemampuan & Kemampuan Reflektif \\
\hline Perempuan & Tinggi & Reflektif \\
\hline Laki-laki & Tinggi & Reflektif \\
\hline Perempuan & Sedang & Reflektif \\
\hline Laki-laki & Sedang & Cukup Reflektif \\
\hline Perempuan & Rendah & Cukup Reflektif \\
\hline Laki-laki & Rendah & Kurang Reflektif \\
\hline
\end{tabular}


S1 perempuan berkemampuan tinggi dan Subjek S2 laki-laki berkemampuan matematika tinggi memiliki kemampuan berpikir reflektif. Walaupun sama-sama mempunyai kemampuan berpikir reflektif dan telah melewati ketiga fase reflektif yakni reacting, elaborating/comparing dan contemplanting subjek S1 perempuan dan subjek S2 laki-laki mempunyai pembeda yakni subjek perempuan lebih runtut dalam menuliskan informasi contohnya diketatui, yang ditanya, dijawab dan menuliskan kesimpulan pada akhir penyelesaian, sedangkan subjek laki-laki mengarah dalam penggunaan perumpamaan contohnya menggunakan gambar dan tidak terlalu runtut dalam menyelesaiakan jawaban terbukti pada Gambar 2.

Pada subjek berkemampuan sedang S3 perempuan dan S4 laki-laki terdapat perbedaan. Subjek S3 memiliki kemampuan berpikir reflektif sedangkan S4 cukup reflektif. Sedangkan perbedaan lainnya yaitu dalam cara penyelesaian soal S3 menuliskan secara detail apa saya yang diketahui dalam soal, membuat perumpamaan yang memudahkan dalam menyelesaikan soal. Subjek S3 juga menuliskan dengan runtut tahapan dalam menyelesaikan masalah dengan menuliskan yang diketahui, dipertanyaakan dan jawab. Sedangkan subjek S4 langsung menjawab penyelesaian dengan singkat. Subjek S4 laki-laki menggangap bahwa lebih cepat mengerjakan langsung karena tidak banyak membuang banyak waktu.

Pada subjek S5 perempuan berkemampuan rendah dan subjek S6 laki-laki berkemampuan rendah memiliki kemampuan berpikir reflektif berbeda. S5 perempuan mempunyai kemampuan cukup reflektif dan subjek S6 laki-laki mempunyai kemampuan kurang reflektif. Selain itu dapatkan perbedaan bahwa saat menyelesaiakan soal subjek S5 menuliskan dulu informasi yang diketahui dan dipertanyakan, sedangkan S6 secara langsung mengerjakan soalnya tanpa menuliskan informasi yang didapatkan. Tetapi kedua subjek berkemampuan rendah ini tidak dapat memberikan kesimpulan pada penyelesaian masalah yang ada.

Temuan dalam Pengkajian ini adalah bahwa kemampuan berpikir reflektif siswa dalam luas lingkaran tidak mempunyai jenjang berpikir reflektif sama. Semua keenam subjek pada penyelesaian luas lingkaran memperggunakan caranya masing-masing dengan menuliskan secara runtut informasi yang didapat atau memisalkan dengan gambar. Ditemukan juga bahwa gender tidak mempengaruhi dalam tingkat berpikir reflektif, terbukti bahwa subjek perempuan memenuhi tahapan berpikir reflektif yang berbeda, begitu juga dengan subjek laki-laki mempunyai tahapan berpikir reflektif yang berbeda.

\section{KESIMPULAN}

Mengacu hasil penelitian dalam pembahasan bisa disimpulkan dengan kemamapuan berpikir reflektif subjek berkemampuan yang tinggi, kemampuan yang sedang, dan berkemampuan rendah tidak berpengaruh dalam fase berpikir reflektif yang tidak berbeda. Subjek Perempuan, subjek lakilaki kemamapuan tinggi dan subjek perempuan berkemampuan sedang melewati 3 fase reflektif yaitu reacting, elaborating/comparing, dan contemplanting dan dikatakan reflektif. Subjek laki-laki 
berkemampuan sedang dan subjek perempuan yang berkemampuan rendah mempunyai kemmpuan cukup reflektif. Sedangkan subjek laki-laki yang berkemampuan rendah mempunyai kemampuan kurang reflektif. Perbedaan kemampuan Reflektif ini terjadi dikarenakan kurangnya ketelitian yang lakukan oleh subjek, selain itu dipengaruhi oleh kurangnya strategi dalam menyelesaikan soal. Solusi agar dapat memenuhi kriteria dalam berpikir reflektif siswa diharapkan untuk lebih teliti, dan lebih lengkapa menuliskan semua informasi yang diberikan.

\section{DAFTAR PUSTAKA}

Ananda, R., Febrian, \& Tambunan, L. (2019). Analisis Kemampuan Berpikir Reflektif Matematis Dalam Menyelesaikan Soal Operasi Pecahan Campuran Pada Kelas Vii Sekolah Menengah Pertama Negeri 14 Satu Atap Tanjungpinang. ARTIKEL E-JOURNAL.

Ariestyan, Y. Sunardi, Kurniati, D. (2016). Proses Berpikir Reflektif Siswa dalam Menyelesaikan Soal Matematika materi Sistem Persamaan Linier Dua Variabel. Kadikma, 7(1), 95-104.

Demirel, M., Derman, I., \& Karagedik, E. (2015). A Study On the Relationship Between Reflektive Thinking Skills toward Problem Solving and Attitudes toward Mathematics. Hacettepe University.

Fuady, A. (2017). Berfikir Reflektif Dalam Pembelajaran Matematika. JIPMat, 1(2). https://doi.org/10.26877/jipmat.v1i2.1236

Nurman, T. . (2008). Profil Kemampuan Siswa SMP dalam Memecahkan Masalah Matematika Open Ended Ditinjau dari Perbedaan Tingkat Kemampuan Matematika.

Purwokerto, U. M., \& Belakang, L. (2018). Throwing Pada Mata Kuliah Teori Graf Kemampuan Pemecahan Masalah. 2, 48-59.

Putri, A. S., \& Mampouw, H. L. (2018). Profil berpikir reflektif siswa dalam menyelesaikan soal tipetipe perkalian ditinjau dari perbedaan kemampuan matematika dan gender. Math Didactic: Jurnal Pendidikan Matematika, 4(1), 34-46. https://doi.org/10.33654/math.v4i1.81

Sugiyono. (2015). Metode Penelitian Kuantitatif, Kualitatif, dan R\&D. Alfabeta.

Supriyaningsih, N., Prihatnani, E., Matematika, M. P., Kristen, U., Wacana, S., Matematika, D. P., Kristen, U., \& Wacana, S. (2016). Profil Kemampuan Berpikir Reflektif Siswa SMP Dalam Menyelesaikan Soal Matematika Pisa Pada Konten Quantity. Prosiding Seminar Nasional Etnomatnesia, 2012, 366-378.

Suriasumantri. (n.d.). Ilmu dalam Perspektif. Yayasan Pustaka Oboer Indonesia.

Tuncer, M. Ozeren, E. (2012). Prospective teachers evaluations in terms of using reflective thinking skills to solve problems. Procedia Sosial and Behaviora Sciences. hhtps://www.researchgate.net/pblication/271880996_Prospective_Teacher's_Evalution_in_Ter ms_of_Using_Reflective_thinking_skill_to_Solve_Problems

Ulvah, S., \& Afriansyah, E. A. (2016). Kemampuan Pemecahan Masalah Matematis Siswa ditinjau melalui Model Pembelajaran SAVI dan Konvensional. Jurnal Riset Pendidikan, 2(2), 142-153. 
http://hikmahuniversity.ac.id/lppm/jurnal/2016/text07.pdf 